\title{
運動視差及び両眼視差による 奥行きの水平線分キャプチャー
}

\section{斎田真也 \\ (工技院・製品科学研究所)}

The capture of horizontal lines by the depth from motion parallax or binocular parallax.

Shinya SAIDA (AIST, Industrial Products Research Institute)

〔目的〕Roger \& Graham 1)が被験省の部部 进動に闹期して进動祝空刺激を提示すれ ば、形成される奥行きの量と方们は一義的

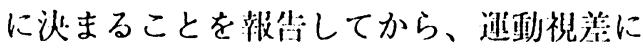
阙する倾究は湓発化してきている。

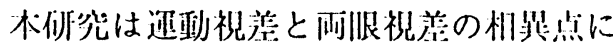

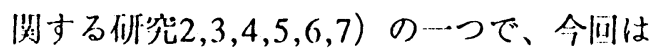

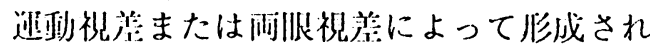
た舆行きを持つ表而に視差成分を们しない 水沪線分が如们に付街するか、すなわ进

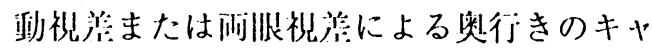
プナャーに阅する版究である。

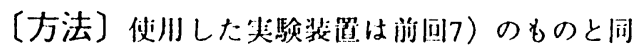
栐て、：つのCRTディスプレイからなり、页いの 管洏はハーフミラーにより-.つの西酒に融像され

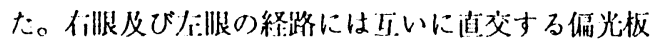

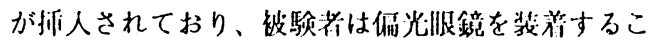

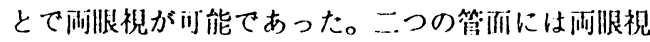

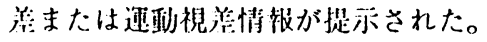

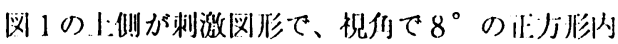

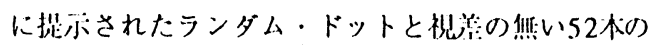
水平線分が目权合わされて提示された。ランダム。

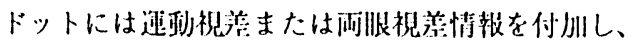

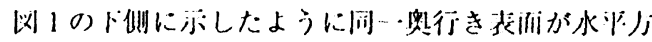

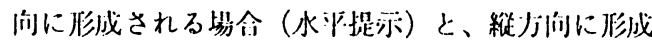

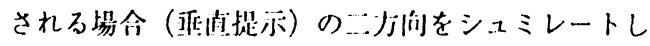

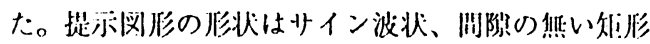

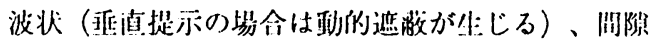

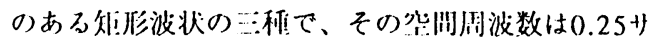
イクル/度である。

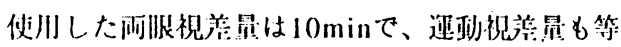

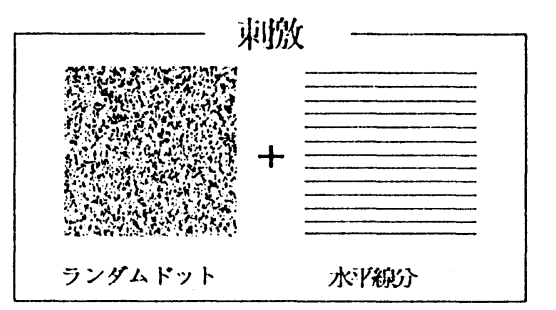

但视养:

(1) m i nで あ つ た。し たがっ 厂シュ ミレー トした 奥行き は背に $6 \mathrm{~cm}$ あ っ た。 被験 若は钼 綮距踓 $50 \mathrm{~cm}$ て の 洏服 江体視 打 20 " 小大 举抽 9 名を川 いた。 彼りは 蜎台に 戴部を 渠せ心: 有に速

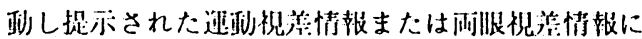
より知絲した奥行きの表而に視美の與い水仠線分が

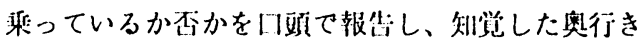


量を二つのポインタの閒隔にて実験者に報告し た。各条作で8四の硯察を行なった。

〔結果および考察〕 9 人の被験桨の头约倠

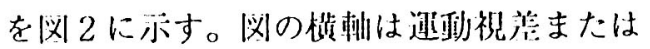

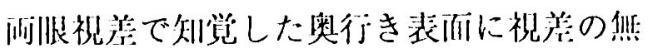
い水头線分がチャプチャーされる频㡲 （\%）で、紸厅问は提示波䚲の版状で、上

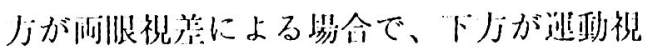
富による晹命である。

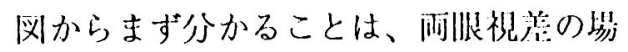
合と通䣦视等の埸合とでほほ同じ倾们を示

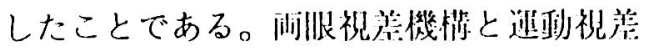
機槛との颣似性: はこでも倠哂さされた 2,3,4,5,6)。㺫ち舆行きが水線分をキャプ チャ一する频度は、その奥行きが速㳩视等 によって䚲成されたものであっても、河师 视策によって䚲成されたものであってもほ

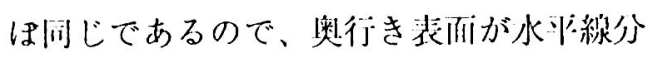
をキ+プチャ一する機篮は一つであると考 えられる。

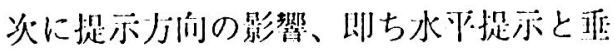
田提小との䦽いを見てみると、サイン波の

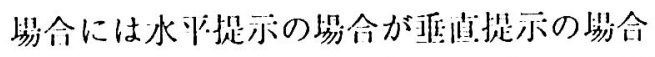
に比べて乍意に $(p<0.01)$ キャプチャ一頪

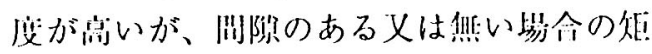

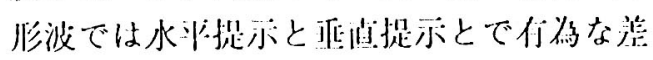
がなかった。このことは水棌分は本米间

一の跅離にあると解秋するのが最も自然と 考えられ、このことから最もかけ踓机た状

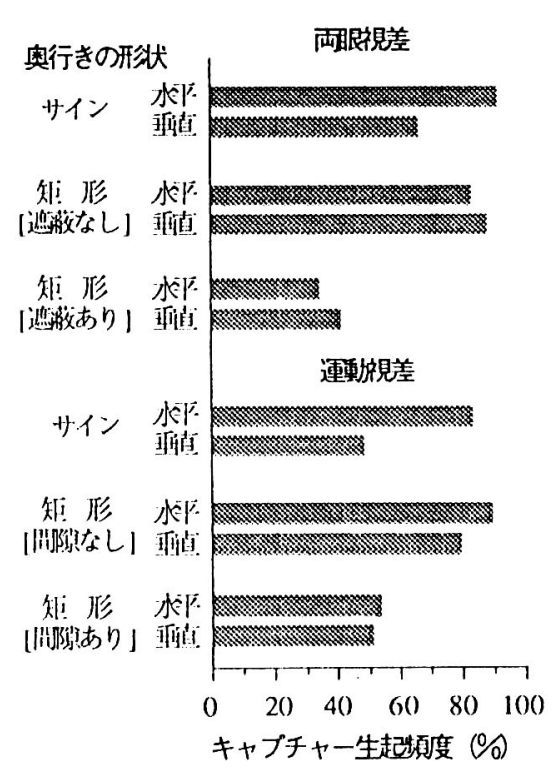

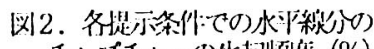

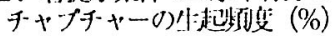

態にキャプチャーされる晹命が命国ではサ イン波近备提小であったと考えられる。

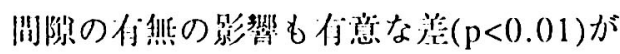
認められ、悶腙がない埸命の方がキャプ

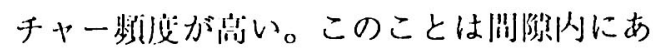
る水将線分及び線分の一部尔他の水刵線分 がキャプチャーされるのを妨げていたと考 えられる。

〔結論〕奥行きによる水平線分のキャプ チャーは、その奥行きが運動視差によるも のでも両眼視差によるものでも同じ特性特 性であった。

\section{参考文献}

1) Rogers B. and Graham M. (1979) Perception, 8, 125-134.

2) Graham M. and Rogers B.(1982) Perception, 11,247-262.

3) Rogers B. and Graham M. (1982) Vision Res., 22, 261-270.

4) Rogers B. and Graham M.(1983) Science, 221, 1409-1411.

5) Rogers B. and Graham M. (1984) In Sensory experience, adaptation, and perception.

Eds. L.Spillmann and B.R.Wooten (Lawrence Erlbaum Associalcs, Hillsdale, New Jersey,) (x)3-619.

(6) Rogers B. and Collett T. (1989) Q. J. Exp. Psychol., 41A, 697-717

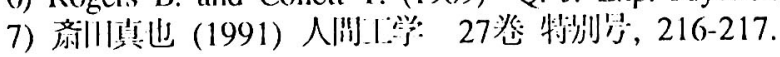

